\title{
FLORAL BUNDLE FUSION AND VASCULAR CONSERVATISM
}

\author{
Rudolf Schmid*
}

\section{Summary}

Critiques are presented of the three main precepts of vascular conservatism, viz.: (r) extent of fusion of bundles denotes degree of evolutionary advancement; (2) 'vestigial traces' indicate organs that have disappeared because vascular patterns lag behind in evolution; and (3) orientation of bundles demonstrates homologies. Precepts (2) and (3) can be controverted to a large extent by existing reports in the literature. Precept ( $\mathrm{I}$ ) is herewith tested by an analysis of the level and manner of origin of the dorsal carpellary bundles of four species of Syzygium s.l. (Myrtaceae). These features are very variable in an individual plant and even in a single flower. Consequently, the extent of union between bundles, contrary to widespread belief, is not necessarily a reliable indicator of phyletic status of an organ or taxon. There is no a priori reason to expect hypotheses based upon conservatism to apply to all situations. The only ultimate test is correlation with other lines of evidence.

\section{Background}

In spite of the recent burgeoning of data from such sources as comparative chemistry, cytology, and other so-called "new approaches", the phylogenetic relationships of plants are still evaluated largely on the basis of systematic studies of structural characteristics, both histological and organographic. Particularly at the taxonomic levels of genus, family, and above, the classical comparative methods are still pre-eminent.

A cornerstone of much morphological and anatomical work in higher plants is the alleged principle of vascular conservatism, namely, the premise that vasculature of organs is less variable than the external parts. Consequently, it is believed that vascular patterns can reveal information on the phylogeny of a group or organ not obtainable with such assurance from gross morphological studies. Carlquist (1969) recently presented a colorful commentary on the subject. Although many of his arguments against vascular conservatism had been expressed by earlier workers (see particularly Arber, 1933a; Goebel, I932-33, pp. I I I4-I 517, I831-1832; Grélot, I 897; Hall, 1956; Thompson, 1937), this is the first time in a single paper that these arguments were presented with such cogency. Carlquist's ( 1969 ) main contention is that vascular conservatism is an inadequate and fallacious basis for phylogenetic interpretations of floral anatomy and that "anatomy of flowers can be studied meaningfully only in relation to adaptations for particular modes of pollination, dispersal, and allied functions" (p. 334).

The concept of vascular conservatism, as initially formulated by Henslow (1888, especially p. 283 ; rudiments of the idea appear in Brown, 1833 ,

* Department of Botany, The University of Michigan, Ann Arbor 48ro4. Present address: Department of Botany, University of California, Berkeley, Calif. 94720. 
pp. 697-698) and later popularized especially by Eames (1929, 1930, I931, 196r; Eames and MacDaniels, 1925, 1947), has three main precepts: (I) The extent of fusion of vascular bundles indicates degree of evolutionary advancement since bundles, being conservative, may remain separate or partly separate even though the structures they supply have become connate or adnate. (2) Patterns of vasculature tend to lag behind in evolution so that what are termed "vestigial traces" indicate structures that have otherwise disappeared. (3) The orientation of bundles, i.e., xylemphloem relationships and trace divergence, may be used to interpret homologies. Consequently, vasculature "may reveal the former boundaries, relative positions, numbers, and categories of organs, or their parts, which may now be obscured by reduction, connation, and adnation" (Moseley, 1967, p. 160, emphasis his). Most workers, however, do not accept the opposite concept that vascular bundles by themselves may represent prophetic forerunners of future parts (e.g., Henslow, I 888) since this ascribes complete priority of vasculature over external form.

The third precept, orientation of vascular bundles, has figured importantly in considerations of the morphological nature of the placenta (for good reviews see Eames, 1961; Majumdar, 1956; Moeliono, I970; Puri, I95 I, 1952b). Suffice it to say, this feature must be used with great caution (I) because orientation may change during development (Majumdar, i956; Moeliono, 1970, p. 133; Swamy and Periasamy, 1964), (2) because it is of ten variable, even in the same flower (e.g., Moeliono, 1970, pp. I 34-I 39; Moseley, I96I, I965), (3) because inverted, collateral bundles may simply be related to the division of amphicribral bundles (Moeliono, 1970), (4) because determination of the orientation of bundles, as a result of slight phloem development or lack of lignification, can be very subjective, and ( 5 ) because the applicability of this criterion in cases with bicollateral and amphicribral bundles is usually impossible. Proponents versus opponents of this precept are, respectively, Cusick (1966), Eames (I95I, I96I), Henslow (r888, r890), Moseley (1965, I967), Puri (1945, I95 I, I952b, 196r), and van Tieghem (1875) versus Arber (1938), Carlquist (1969), Eggers (1935), Goebel (1932-33), Grélor (1 897), Majumdar (1956), Moeliono (1970), Rao (1968), and Swamy and Periasamy (1964). In view of the foregoing contingencies, orientation of vascular bundles may hardly be regarded as rigidly conservative!

The precept of vestigial traces has been the cause of so much discordance about vascular conservatism that, in the minds of many botanists, conservatism and the idea of vestigial traces have become nearly synonymous. "Vestigial traces" have been severely and frequently criticized (e.g., Arber, r933a, b; Carlquist, I96r, P. I 32, I 969; Cheung and Sattler, r 967; Eggers, 1935; Goebel, 1932-33; Grélot, 1897; Hall, 1956; Rohweder, 1967; Stebbins, 1967; Thompson, 1936, I937). Some of the salient criticisms adduced (with examples of workers favoring various aspects) have been the following:

(I) Vascular bundles from in relation to parts of the plant body (e.g., Arber, 1933a; Carlquist, 1969; Eggers, 1935; Goebel, 1932-33; Grélot, I897; Hall, 1956; Rohweder, I967; Stebbins, I967). So-called vestigial traces arise in association with primordia that stop growing early in their development and then merge with and become obscured by the surrounding tissue (e.g., Carlquist, 196r; Hall, 1956; Stebbins, 1967). The vascular tissue thus persists as a "vestigial trace", as a simple byproduct of inter- 
actions between normal developmental processes. The point is that the strand, by itself, is not complete: the entire vestige includes not only the strand, but also the organ which had ceased its development at an early stage. Most so-called vestigial traces have been detected in analyses of mature flowers, but ontogenetic study should reveal that the organ itself is indeed represented and is merely obscured by overgrowth. The true vestige, then, is not simply the trace, but the abortive organ of which it is a part. One should not jump to the conclusion, however, that all ontogenetic emergencies and(or) "blind" vascular strands are necessarily vestigial. Corollaries of this criticism include the following:

(a) Vascular bundles are determined solely by functions of contemporary structures (e.g., Carlquist, r969; Crüger, I865; Eggers, I935; Goebel, I $932-$ 33; Grélot, 1897; Rohweder, 1967; Stebbins, 1967; Thompson, I936, 1937). Hence, according to some authors (e.g., Carlquist, 1969; Stebbins, I 967), bundles should be interpreted as functional structures resulting from physiological factors and not merely as relics betraying the evolutionary loss of organs.

(b) Vascular patterns vary with change in external form and magnitude (e.g., Carlquist, 1969; Eggers, 1935; Goebel, 1932-33; Hagemann, 1963; see also Wardlaw, 1965). That is, vasculature is opportunistic, the shape and size of the developing organ controlling the pattern and amount of vasculature to a large extent. Obviously, there is a correlation between over-all shape of an organ and its vasculature. But, in addition, large organs will usually have many, highly branched strands, whereas small organs will have but few. The role of vascular amplification and reduction has not really been sufficiently considered with respect to vascular patterns.

For example, in Syzygium s. l. species with large flowers such as $S$. jambos, $S$. malaccense, and $S$. aromaticum (average maximum floral bud size 9.2 by $18.2 \mathrm{~mm}$ ) have closed vascular systems, whereas species with small flowers such as S. cumini, S. paniculatum, Cleistocalyx operculatus, and Acmena smithii (average maximum bud size 3.0 by $4.9 \mathrm{~mm}$ ) have open or essentially open systems. A number of other features of vasculature are also largely or entirely correlated with size of flowers in Syzygium s.l. (see Tables I, II in Schmid, I 972b): for example, (A) large flowers (I) with bundles of the floral tube in a scattered arrangement (the zonocyclic condition - see Schmid, I972a), (2) with numerous lateral carpellary and stylar bundles, (3) with a massive placental ring, (4) with distal extensions of the axile ovular system present, $(5)$ with large perianth parts containing many highly branched bundles, and (6) with sclerenchyma (sclereids and/ or phloem fibers) distributed throughout the floral tube and ovary, versus (B) small flowers (I) with bundles of the floral tube zonocyclic or arranged in a ring (the monocyclic condition - see Schmid, I972a), (2) with few lateral carpellary and stylar bundles, (3) with a small placental ring (or this lacking), (4) with distal extensions of the axile ovular system absent, (5) with small perianth parts containing few, less extensively branched bundles, and (6) with sclerenchyma lacking or restricted to the base of the flower. These characters ( $A_{1}, A_{3}, A_{4}$ versus $B_{2}, B_{5}, B_{6}$, essentially open system), however, are fairly well combined in the intermediate-sized C. myrtoides (bud size 4.2 by I $4 \mathrm{~mm}$ ). Such factors of size (see Bower's, I 935 , views on size and form in plants) seem to have been little appreciated by floral anatomists, many of whom hold a static view of floral structure 
because of their focus upon the bud near the stage of anthesis (see Carlquist, r969; Moeliono, 1970).

(c) The foregoing conclusions are bolstered by consideration of the complex vasculature (including profuse anastomosing in an irregular pattern) that is apparently normal for most medium- and large-sized fruits (and flowers as well). Such amplification of patterns of strands probably functions for strictly nutritional reasons related to the necessity of sufficient vascular tissue to serve an increased amount of ground tissue. Are we then to assign vestigial-bundle status to each of the many strands in a cucurbit fruit? As Carlquist (1969) emphasized, it is unlikely that bundles in fruits can be interpreted as vestiges since fruit types are very plastic and phylogenetically interconvertible. Since the vasculature of the flower is simply a precursor of vasculature of the fruit, the designation of bundles as "vestigial" in unfertilized carpels must be viewed sceptically (e.g., Carlquist, 1969).

(2) There is no reliable relationship between the presence (or absence) of the organs and the presence of vascular strands. It has been shown that primordia and mature organs sometimes exist without provascular or vascular tissue (e.g., Arber, 1933a; Carlquist, 1969; Cheung and Sattler, 1 967; Goebel, 1932-33; Thompson, I937; see also Puri, 195 I, p. 483, for additional examples). This is counter to the doctrine of vascular conservatism, which postulates that provascular and(or) vascular tissue should occur, even without primordia or mature organs. This is probably the most compelling criticism, namely, that the so-called vestigial traces frequently are not found where they would be "expected" (e.g., Carlquist, I 969; Hall, I 954, I956; Joshi, r940). Thus their sporadic or variable occurrence indicates their lack of phylogenetic dependability (e.g., Carlquist, 1969).

(3) The preceding comments point to the conclusion that whether or not given bundles are vestigial is inevitably a matter of subjective interpretation (e.g., Arber, 1933b; Carlquist, 1969; Hall, 1956). In fact, Eames himself (in a 1954 letter to Warren $\mathrm{H}$. Wagner, Jr., used by permission of the latter) indicated vestigial traces can not be demonstrated and "interpreted except by unusually good students" and that "critical staining" and the experience of "a well trained anatomist" are necessary. Such hedging, even by the master of vestigial traces, suggests that their utility is highly questionable. Finally, there is no way to forestall what Carlquist (1969, p. 336) refers to as "overly literal" interpretations of so-called vestigial bundles.

In fairness to adherents of vestigial bundles ${ }^{1}$, it should be noted that Saunders (1934), Ozenda (1949), Puri (1951), and especially van Heel (r969) attempt the most detailed rebuttal to some of these criticisms, but the arguments of these authors are far from convincing.

It is the first precept - conservatism of bundle fusion - that has received

I. Personalities include: Arber, r 913 , but not 1933a, b; Beauverie and Durand, 1930; Bower, 1935, p. 564; Constance, I955; Douglas, 1944; Eames, 1929, 1930, 1931, I953, 196r; Eames and MacDaniels, 1925, 1947; Fahn, 1967; van Heel, 1966, 1969; Henslow, I888; Hunt, 1937; Joshi, r933; Kasapligil, 1951; Kozo-Poljanski, 1936; McLean and Ivimey-Cook, 1956; Melville, 1963; Moseley, 1967; Ozenda, 1949; Puri, 1951, 1952C, 1962; Saunders, 1934; Wilson, 1950; Wilson and Just, 1939. 
little criticism and analysis, even by Carlquist ( 1969 ) in his demolitionary critique of floral anatomy. Indeed, Carlquist (1969, p. 336) stated that "lagging in degree of union of bundles (really not conservatism at all, strictly speaking) is the only clear exception to evolution of vascular bundles contemporaneously with evolution of other floral features". In addition, Eyde (197I, p. 7I) recently stressed that the extent of union of floral bundles is a reliable indicator of amount of evolutionary change, although he admitted that in view of recent demonstrations of apparent reversals of widespread trends (Eyde and Tseng, I969; De Wet, 1968), "it would be too much to expect that the union of vascular bundles will stand forever as an irreversible evolutionary trend". In contrast, Carlquist very recently informed me (Aug., 197I) that he has become very skeptical of the use of extent of bundle fusion as an indicator of phylogeny since "it is just as possible to draw wrong conclusions on the basis of degree of union as on any other feature of floral vascularization".

Systematists have long been cognizant of variability in plants, and in more recent times have been enabled to cope with it (see Davis and Heywood, I963; Stebbins, 1950). On the other hand, the anatomists have all too often taken a simplistic view of variability. Complacent that they are employing a "broadened outlook" (Bailey, I949), of ten one in the context of the "New Morphology" (see Bailey, I 949; Corner, 1966; Eames, 195I; Moeliono, 1970), anatomists have perennially argued that endomorphic characters are more important than exomorphic ones, largely because the former are "not exposed directly to the environment". However, there is considerable evidence that such an assumption is not necessarily valid and that anatomical characters are inherently no more reliable than exomorphic ones (Bailey, 1951, 1953; Davis and Heywood, 1963). On the other hand, I am hesitant to subscribe wholly to the opposite view that exomorphic characters "are probably the most reliable criteria for understanding of phylesis of flowers and fruits" (Carlquist, 1969, p. 342). One suspects that endomorphic characters are neither more nor less conservative or reliable than exomorphic characters, and that both vary in their conservatism among various groups.

The bible of allegedly conservative endomorphic characters has been, of course, the vascular system. The analogy with zooid skeletal systems is readily, albeit erroneously, made (e.g., see Eames, 1929, Hunt, 1937, and Ozenda, 1949, versus Carlquist, 1969, and Rohweder, 1967). Floral anatomists seem to have a particular insistency upon the gospel of vascular conservatism, no doubt because they believe that floral strands represent what might be called "double" conservatism, i.e., vascular tissue together with reproductive structures (e.g., Eames, 1929, p. 424). In its most diabolical form, the idea of vascular conservatism could become a deceptive shortcut to phylogenetic conclusions. A floral anatomist would need only to consult the bundles of a flower to obtain its deepest secrets, whereas the poor general taxonomist must struggle with a host of characters. Floral anatomy would then be what Arber (1933a, p. 240) called "a reliquary to be rifled for 'ancestral traits' ".

Despite pleas for a "broadened outlook" (Bailey, I949), an "expanded outlook" (Lawrence, I953), or for a "broad comparative" or "synthetic approach" (van Heel, 1969, and Puri, 1960, respectively), and particularly because of the lure of "double" conservatism referred to above, floral anatomists have generally been more remiss than other botanists in their 
concern with variability and in their concomitant exploitation of vascular conservatism. A real danger of vascular conservatism is that its convenience and deceptive simplicity enable anatomists to ignore variability in plants and to indulge in unbridled speculation about the phylogenies of groups and structures. As Arber (1 933b) emphasized, workers treat conservatism "not as a hypothesis which demands proof, but as a postulate upon which further argument can safely be based". Such "facts" in turn become incorporated into our thinking, reinforcing the dogma of the time. And so the circle goes on ever widening.

Although a number of workers in floral anatomy have already depicted variability of organography or histology (e.g., Jayaweera, I956, 1957; Kasapligil, I95I), very few have specifically bothered with variability of vasculature (e.g., Hall, r954; Schmid, r97 I, I972d; Venning, 1948), a concern crucial to the doctrine of vascular conservatism. Venning (I948) sectioned 44 floral buds, flowers, and young fruits from two plants of the rutaceous tree Pamburus missionis, and found, often within a single flower, the three types of fusion between bundles of the petals and sepals that Tillson and Bamford (1938) had regarded as of probable taxonomic importance in their survey of 94 species in 29 other genera of the Rutaceae. Venning ( 1948 , p. 142 ) concluded that "when so wide a range in the degree of complexity of floral vascular pattern is found within a single species, and even within a single flower of that species, it is difficult to see how much phylogenetic significance can be attached to the evidence afforded by the vascular anatomy of that species". Hall (I954) sectioned 33 flowers from 10 trees of Acer negundo, found comparable variability in the vasculature, and he also doubted that "the floral vascular skeleton, at least in the maples, is more 'conservative' than any other characters" (p. 532).

\section{Analysis}

In view of the above, I shall present here (I) the results of a test of the conservatism of vascular fusion and (2) a criticism of this precept. Hall (1954) and Venning (1948) each studied the variability of floral vasculature within a single species. However, investigation of variability of vasculature of several species within a natural assemblage is more significant since a single species examined in isolation might prove atypical in its variability. Accordingly, I examined many flowers of four species of Syzygium s. $l$. for which I had sufficient material: Cleistocalyx operculatus (Roxb.) Merr. et Perry, Syzygium cumini (L.) Skeels, S. paniculatum Gaertn., and Acmena smitbii (Poir.) Merr. et Perry. The variability of vasculature detected for these four species is representative of that of other species of the Myrtaceae I examined (Schmid, I 97 I, I $972 a-c$ ).

I analyzed the extent of union between dorsal carpellary bundles and peripheral bundles in detail (I) because of the significance of the dorsals in the classical concept of the carpel, (2) because they are topologically easy to detect, (3) because the occurrence of just two dorsals per flower (of Syzygium) facilitates their diagrammatic representation, and (4) because this feature, namely, degree of fusion of dorsals with peripherals, was used recently by Eyde and Tseng (I97 I) in a study of the floral vasculature of the Araliaceae. Other features in Eugenia s. l., particularly the lateral carpellary bundles, are much more variable than the dorsal carpellary bundles and were not analyzed because of various complexities. For 
example, the lateral carpellary bundles range in number from zero (Cleistocalyx operculatus) to about 20 per flower ( $S$. jambos), and in many species ( $S$. jambos, $S$. malaccense, $S$. paniculatum, most species of Eugenia s. s.) anastomose in a very complicated manner (Schmid, 1972b, c).

Figures $\mathrm{I}$ to $3^{8}$ present the range of variability in level and manner of origin of the dorsal carpellary bundles in 38 buds, flowers, and young fruits of four species of Syzygium s. l. (forty other cleared and sectioned flowers were also examined but could not be depicted by this method of analysis). The figures for each species are based on flowers from a single plant (except Fig. I 3 which represents a second collection of S. cumini) and are arranged with the degree of union between the dorsal carpellary and peripheral bundles varying from the most to the least fusion. The vertical distribution of points on the diagrams was accurately determined by measurement (in the case of clearings and longisections) or by counting the number of paraffin sections (in the case of transections) from various reference points. The horizontal distribution of points on the diagrams was approximated. To facilitate comparisons all ontogenetic stages (young buds to young fruits) were plotted to the same scale, since detailed analysis of the vasculature of $S$. paniculatum revealed no correlation between ontogenetic stage and the level of origin of the dorsal bundles. The union of the lignified portions of bundles was taken as the indication of fusion of bundles since in $S$. cumini and $S$. paniculatum, bundles, which are largely amphicribral, frequently become briefly contiguous by their unlignified portions. Since clearings by themselves are frequently misleading, the captions to Fig. I to 38 indicate which of the diagrams were based upon transections and longisections and which upon clearings.

The diagrams (Fig. $1-38$ ) show that there is much variability in the level of origin of the dorsal carpellary bundles. Acmena smithii (Fig. 3338 ) is the least variable in this respect, but in the other three species (Fig. I-32) the dorsals may arise anywhere from near the base of the flower to near the tops of the loculi. Remarkably, the two dorsals of a single flower of ten arise at very disparate levels (Fig. 5, 7-9, I6, 22-24).

Figures I to 38 also show that there is some variability in the manner in which the dorsal carpellary bundles originate ${ }^{2}$. Usually the dorsals simply arise as a branch of another bundle, as in all flowers of Cleistocalyx operculatus and Acmena smithii (Fig. 1-9, 33-38). However, sometimes in Syzygium cumini and $S$. paniculatum the dorsals originate by the fusion of two or more branches arising either from different bundles (Fig. ro, II, 23) or from the same bundle (Fig. 27). In several cases (Fig. 23, 27) one of the several branches comprising the dorsal carpellary bundle consists largely or entirely of unlignified elements. Similar as well as other types of variations occur in other species of Eugenia s.l. (Schmid, $1972 \mathrm{~b}, \mathrm{c}$ ).

The diagrams for Syzygium cumini and S. paniculatum (Fig. I0-32)

2. Eames (1931), Henslow (1890), Moseley (1961), among others, consider as significant in the evolutionary process of adnation the fact that 'when the various bundles become free, the separation is often by a tangential split, and not by a radial division, as would be the case if these bundles were departing from a stele' (Eames, 1931, p. 190I, emphasis his). In Syzygium paniculatum and other species the direction of divergence of the dorsal carpellary traces varies from radial to tangential, both conditions sometimes occurring in the same flower. 

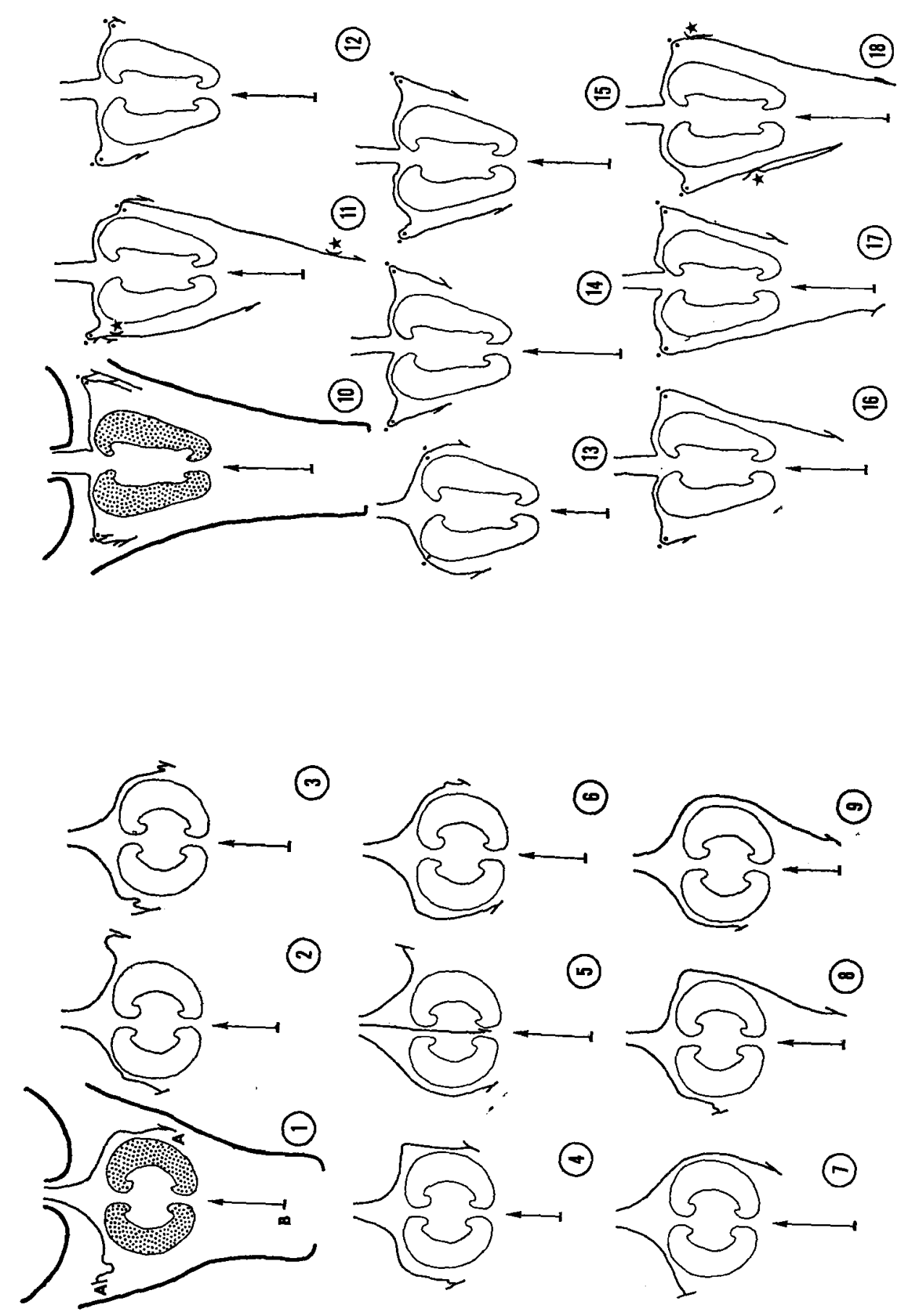

(2) (0)
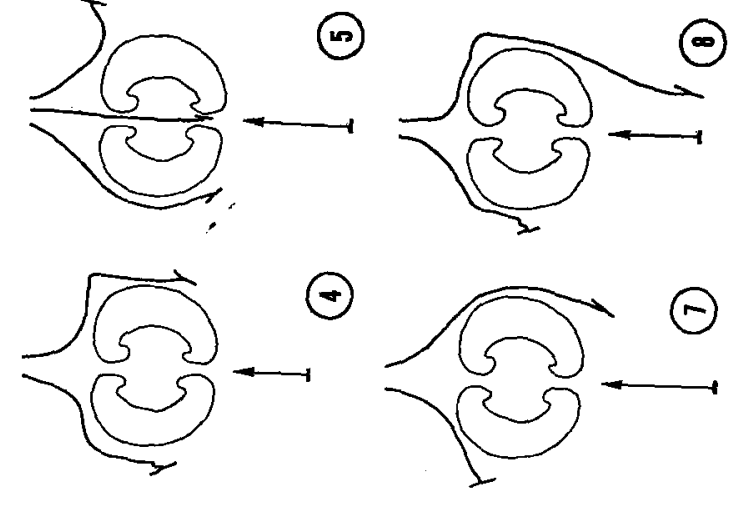
FIG. I-38: Variations in bundle fusions in Cleistocalyx operculatus (Fig. 1-9: Rabmat Si Toroes 3196, MICH.), Syzygium cumini (Fig. 10-18: Kramer and Hekking 2037, MICH.; Fig. I 3 is based on J. and M. S. Clemens 4040, MICH.), S. paniculatum (Fig. 19-32: Schmid 1969-AI, MICH.), and Acmena smitbii (Fig. 33-38: Schmid 1968-A2, MICH.). Figures show origin of dorsal carpellary bundles, to either side of stippled loculi (e.g., ' $A$ ' in Fig. I), and level of origin of axile ovular supply, base of arrow (e.g., 'B' in Fig. I). Outlines of flowers (thick lines) omitted from Fig. 2-9, I I-18, 2032, 34-38 to conserve space. In Fig. 10-32 two dots by a dorsal bundle indicate approximate level of inward divergence of that bundle form peripheral zone of scattered bundles; below this level dorsals are topologically difficult to detect. Stars in Fig. II, I 8, 22, 27, 28, 30, 3I indicate points where two bundles become briefly contiguous by their unlignified elements. Dashed lines in Fig. 23, 27, 30 denote bundles consisting only of unlignified elements. Fig. 2, 5, 7, 9-1 1, 18-33, 35, 37 based on transections; Fig. 34, 36, 38 based on longisections; other figures based on clearings. Dorsals end blindly near tops of luculi in A. smithii (Fig. 33-38). Flower depicted in Fig. $S$ is atypically tricarpellate. Fig. 33 is divided into zones of character states, with index scores of ' $I$ ' to ' 5 ' assigned to each zone for estimating level of departure of dorsal bundles (see legend to Fig. 39-42). 
show yet additional variability. Since vascular bundles exhibit a zonocyclic pattern, the dorsal carpellary bundles are topologically difficult to detect before they have diverged inwardly from the peripheral zone of scattered bundles. In S. cumini (Fig. IO-I 8) this inward divergence of the dorsals consistently occurs at the tops of the loculi, but in S. paniculatum (Fig. 1932) it occurs at various levels. In either case, to determine their level of origin, the dorsals must be carefully located in serial transections below their level of inward divergence. In addition, the dorsals and other bundles in these two species commonly become briefly contiguous by their unlignified elements (Fig. I I, I 8, 22, 27, 28, 30, 31) or of ten lie very close to, but separate from, each other for a considerable distance (Fig. I 8, 19, 23, 27, 30). These features are much less pronounced in species like Acmena smithii and Cleistocalyx operculatus which have their bundles arranged in a monocyclic pattern.

The extent of fusion between the dorsal carpellary and the peripheral bundles is the type of character that can be well expressed by a biometric index. The various levels of the flower at which the dorsals originate can be designated as character states, to which index scores of " $\mathrm{I}$ " to " 5 " can be assigned as shown in Fig. 33 (Eyde and Tseng, I97I, use the Eategories "separate", "intermediate", and "united", but I prefer to score a greater number of character states as shown in Fig. 33). Figures 39 to 42 present histograms showing the distribution of index scores for individual dorsal bundles for each species; average index scores are also indicated.

\section{Discussion}

The data presented above show that degree of fusion between vascular bundles is highly variable. Furthermore, observations of many other species of the Myrtaceae (Schmid, 1971, 1972b, c) indicate that they are equally variable in this respect. I therefore doubt that degree of fusion between vascular bundles is a dependable indicator of phylogenetic progression within the Myrtaceae. In the plants I studied there is considerable variability in both the level and manner of origin of the dorsal carpellary bundles, even within a single flower (Fig. $1-42$ ). The fact that the dorsals may arise at markedly different levels even in a single flower (Fig. 5, 7-9, $16,22-24)$ makes one additionally dubious of the value of this character, unless he is prepared to argue that in such cases one carpel of a flower is primitive whereas the other is advanced!

Just as much, or often even more, variability is encountered in other features of the floral vasculature of Eugenia s. l.: for example, the system of lateral carpellary bundles, the vasculature of the perianth parts, the vasculature of the style and to the placentae, etc. (see Schmid, 1972b, c). The vasculature of flowers of Eugenia s. l. is exceedingly variable whereas their organography is relatively constant (Schmid, I 972a). This is difficult to reconcile with the premise of the doctrine of vascular conservatism that vasculature lags behind external structure in evolution. In view of all this, there seems little in the floral vasculature of Eugenia s. l. to inspire much confidence in an uncritical acceptance of vascular conservatism.

It would be easy and all too tempting to maintain a rigid interpretation of vasculature on the basis of the examination of only one or a few flowers of a species, and, indeed, this has been the bane of many studies in floral anatomy (see Hall, 1956). Obviously such a circumvention of 

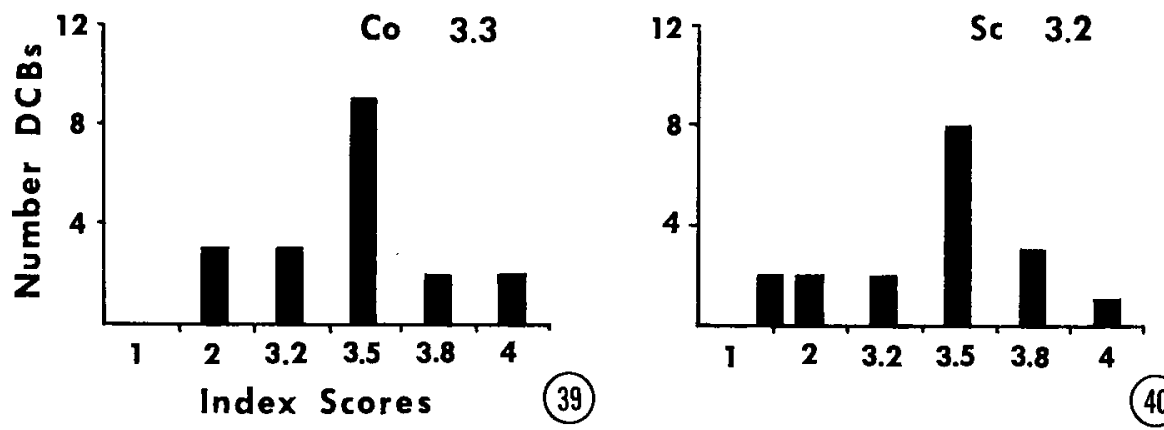

(40)
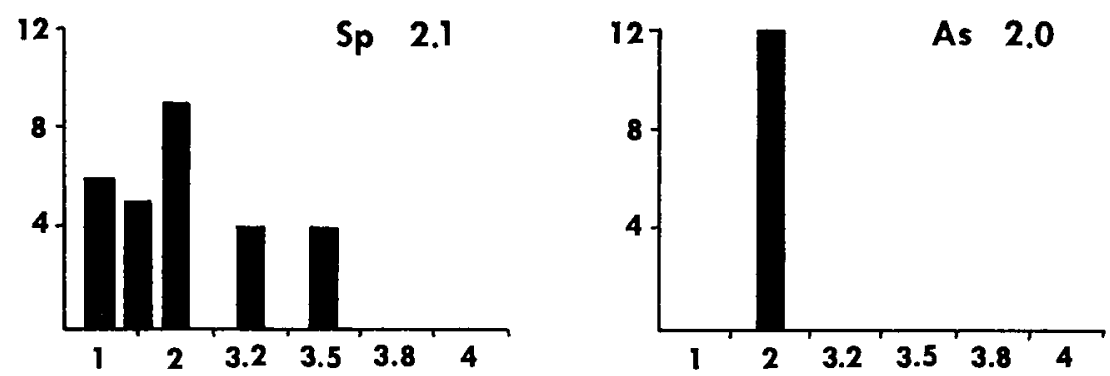

(41)

FIG. 39-42: Histograms of bundle departure variations in Cleistocalyx operculatus (Co, Fig. 39), Syzygium cumini (Sc, Fig. 40), S. paniculatum (Sp, Fig. 4I), and Acmena smithii (As, Fig. 42). Points of origin of dorsal carpellary bundles (DCBs) depicted in Fig. $\mathrm{I}-38$ scored according to zones shown in Fig. 33. Histograms show distribution of index scores for individual dorsal bundles. Number in upper right corner of each histogram represents average index score for species.

natural variability could be very misleading since by chance a single flower showing the extreme of the range of variability might be selected, as Fig. I9 or 32 of Syzygium paniculatum, the flowers of which have average index scores of 3.5 and 1.0 respectively.

Eyde (1971) and Eyde and Tseng (1971) argue that the degree of fusion of vascular bundles should be least in those taxa with the least advanced flowers. By this reasoning, Cleistocalyx operculatus and Syzygium cumini, with average index scores of 3.3 and 3.2 respectively, would appear to be considerably more advanced than either $S$. paniculatum or Acmena smithii, with average index values of 2.1 and 2.0 respectively (Fig. 39-42). However, these average index scores are not necessarily meaningful since my samples of the four species may be inadequate to express their variability. An apparent lack of variability such as that in $A$. smitbii can be deceptive. For example, the first seven flowers of $S$. paniculatum I examined (Fig. 23, 25-27, 29-3 I) appeared to be quite constant (particularly if the unlignified bundle in Fig. 23 is overlooked) and gave an average index score of $\mathrm{I} .6$ ( $\mathrm{I} .8$ if the unlignified bundle in Fig. 23 is counted). Analysis of the next seven flowers (Fig. 19-22, 24, 28, 32), however, revealed much more variability, with extreme average index scores of 3.5 and $x .0$ for a 
flower (Fig. 19, 32), so that the overall average index score for the species was raised to 2.I (Fig. 4I). Consequently, even if the average extent of fusion between bundles were greater in one taxon than in another, the presence of such inordinate variability would seem to preclude attributing conservatism to this character.

Although the level and manner of origin of the dorsal bundles in Eugenia $s$. $l$. is very variable, one should not dismiss the possibility that such variability, or lack of conservatism, is necessarily without phylogenetic significance. On the contrary, such variability may simply indicate a transitional stage that has not yet been stabilized by natural selection.

Because of limitations involving terminology and anatomical methodology (in addition to sampling), I have still other reservations about the reliability of the degree of fusion of bundles as an indicator of evolutionary advancement. The actual designation of the level of origin of the bundles can be difficult and often even arbitrary. When several bundles unite to form the dorsal bundle (Fig. IO, I I, 23, 27), where exactly does the dorsal begin? Overlooking unlignified bundles (Fig. 23, 27), as, for example, in an analysis of clearings or in a cursory examination of sections, might cause misrepresentation of the actual level of origin of the dorsal bundle. However, the occasional seeming contact of dorsal carpellary and other bundles by their unlignified parts (Fig. 28 especially, also Fig. I I, I 8, 22, $27,30,31$ ) should logically be ignored in determining the level of origin of the dorsals since below such contacts the bundles are again separate. In addition, the level of origin of the dorsal carpellary bundle must be ascertained where it branches from a peripheral bundle and not where the dorsal diverges inwardly from the periphery of the flower (Fig. I0-32), although the latter situation may superficially appear more logical. For example, in Syzygium cumini the dorsals all diverge inwardly near the tops of the loculi but actually originate at very disperate levels in the flower (Fig. IO-I 8).

Another reservation about this aspect of vascular conservatism ("union" of bundles") involves evolutionary theory. A cornerstone of the "modern synthetic theory of evolution" is that adaptation is externally directed by natural selection and not internally directed by orthogenesis (the latter perhaps caused by differential mutation, according to Cronquist, 1968, pp. I 20-I 2 I). Orthogenesis as a significant evolutionary mechanism is not in vogue today, particularly in the United States, although in Europe and elsewhere the concept does have its adherents (or, at least, those who doubt the overriding importance of selection in most evolution). As Carlquist (1969) pointed out, most floral anatomists willingly and uncritically choose to hypothesize vascular reduction series and seldom the reverse, namely, increase in vasculature (but see Puri, I952c, for a discussion of amplification of vasculature). The implication seems to be that vasculature is somehow resolutely predisposed to evolve in a certain direction - namely, that of reduction. 'This, of course, smacks of orthogenesis, although most floral anatomists profess to be devout selectionists. If this be so, then this aspect of vascular conservatism ("union of bundles"), at least as expressed in this manner, might be disqualified on the grounds that it is not compatible with the modern synthetic theory of evolution. 


\section{Summary discussion}

The preceding analysis has demonstrated that, at least in the Myrtaceae that I examined, the degree of union between floral vascular bundles is exceedingly variable, both within a species and even within a single flower. Van Heel $(1966,1969)$ also found the level of origin of traces to be very variable in flowers of the Malvales and largely defined by spatial conditions (e.g., a considerable difference in the level of origin of traces could result from a slight change in the position of an organ - van Heel, 1969, p. 190). Van Heel (1966, p. 380) warned that "since it must take variability into account, study of the attachment places [of bundles] is arduous and the results must be used very judiciously".

The degree of union between bundles might be a reasonable evolutionary indicator in certain taxa, and, indeed, the application of this criterion may be the most plausible and parsimonious one in such groups as the Alangiaceae (Eyde, I968), Araliaceae (Eyde and Tseng, I97I), Caprifoliaceae (Eames, 196I, p. 80; Eames and MacDaniels, 1947, p. 351), Ericales (Eames, I93 I, I96r, p. 246; Eames and MacDaniels, I947, p. 354), and Rosaceae (Eames and MacDaniels, 1947, p. 354). However, the degree of union between bundles is not necessarily the reliable indicator of evolutionary status of an organ or taxon suggested by Eyde (1971), and there is no reason why this criterion should apply to all groups. Rather this feature should be regarded as, at best, a potentially very unreliable character that must be applied cautiously, and then only within the framework of (and not as a substitute for) a clear appreciation of anatomical variability in a taxon.

Because vascular conservatism in the Eamesian tradition apparently does not apply in the Myrtaceae, as demonstrated above, or in the Malvales, as van Heel $(1966,1969)$ indicated, one cannot say a posteriori from this that vascular conservatism in all cases is entirely without validity. Obviously conservative characters do exist, probably largely because they are under the influence of strong stabilizing, centripetal natural selection (see Farris, 1966, who gives an operational model for determining conservative characters). Equally obvious is the conclusion that vascular tissue may be conservative in certain situations, at least in the sense that it provides a taxonomically "good" character (see Davis and Heywood, 1963). Vascular conservatism, or one or another aspect of it, might thus pertain in one group of related taxa, but might be of little relevance in another natural group. In addition, some features of vasculature in a group are apt to be more reliable than others. For example, while the degree of union of bundles appears to have little utility in the Myrtaceae, the nature of the ovular supply, whether axile or transeptal, is of considerable significance (Schmid, r $972 \mathrm{a}-\mathrm{c}$ ). These features, however, are no different from any other comparative characters that are employed. Each case must therefore be evaluated separately in conjunction with other lines of evidence. Since vascular tissue is not necessarily conservative, there is no a priori reason to expect hypotheses based upon conservatism to apply to all groups.

Although adherents of vascular conservatism have always been more numerous than opponents or doubters of the concept ${ }^{3}$, the vociferousness

3. Adherents of the concept, or some elements of it, include: Arber, I9r 3 , but not 1933a, b; Beauverie and Durand, 1930; Bower, 1935, p. 564; Brown, 1833; Carlquist, 1961, but not 1969; Constance, 1955; Cusick, 1966; Douglas, 1944, 1957; Eames, 1929, 1930, 1931, I95 I, 
of the latter has perhaps compensated for their lack of numbers. The strongest attack to date on the doctrine of vascular conservatism has been by Carlquist (1969; but see also Arber, 1933a, Goebel, 1932-33, and Thompson, 1937), who, in some of his remarkable statements, recalls, for example, the view of Unruh (1939, p. IIs) that "der Entwicklung eines Organes noch keinem unmittelbaren Aufschluss über seine morphologische Bedeutung geben kann". Workers have tended to hold extreme views about vascular conservatism. In fact, detractors of the concept have been labelled existentialistic (Moseley, I967, p. I60). Nevertheless, a number of workers (e.g., Arber, I91 3; Eames, 1929; Eggers, 1935; Hagemann, r 963 ; Hall, 1954; van Heel, I966, 1969; McLean and Ivimey-Cook, I956; Moeliono, 1970; Moseley, 1967; Ozanda, 1949; Puri, 1951; Wilson and Just, 1939) have tempered their enthusiasm for, or reservations about, the concept with a modicum of compromise.

The crux of the controversy concerning vascular conservatism is whether vasculature is inherently more reliable than other characters (not so according to Bailey, 1951, I953; Davis and Heywood, I963) and whether certain types of evidence from vascular anatomy (vestigial traces, orientation of bundles, degree of fusion between strands, etc.) can be used to establish homologies between structures and to determine directions of evolutionary trends. Inasmuch as there is some doubt about the validity or universal applicability of these aspects of conservatism, for reasons discussed above, dogmas, theories, or phylogenies that are based on these aspects may be precarious at best, erroneous at worst. However, as both proponents (e.g., Eyde, I97I) and opponents (e.g., Carlquist, 1969) of vascular conservatism have rightly emphasized, one very acceptable, legitimate, and uncontroversial use of floral anatomy is in making taxonomic (not systematic!) distinctions.

In conclusion, the most pertinent and clear statement $I$ have encountered regarding the problem of the validity of vascular conservatism is by Léon Croizat, who wrote me (1971) as follows:

It is IMPOSSIBLE to draw a general case for or against the "conservatism" of vascular structures because examples are plentiful to prove and disprove anything you may wish. The POINT is therefore not in arguing about the facts to no purpose, but in showing how Eames, Melville, Saunders, Takhtajan, etc. have gone wrong in making of "conservatism" a cornerstone of their morphology. THAT IS THE POINT, ... not the confused denials, etc., which plague the literature. [emphasis his.]

1953, 196r; Eames and MacDaniels, r925, r 947; Egler, 1951; Eyde, I971; Fahn, I967; van Heel, 1966, 1969; Henslow, 1888, 1890; Hunt, 1937; Joshi, 1933, but not 1948; Kasapligil, 1951; Kozo-Poljanski, 1936; McLean and Ivimey-Cook, 1956; Melville, 1963; Moeliono, 1970; Moseley, 1961, 1965, 1967; Ozenda, 1949; Puri, 1945, 1951, r952b, c, 1960, 1962; Rao, I951; Saunders, 1934, 1937, 1939; Tepfer, I953; van Tieghem, r875; Wilson, 1950; Wilson and Just, 1939.

Opponents or doubters include: Arber, r933a, b; Carlquist, 1969; Cheung and Sattler, 1967; Croizat, 1960, p. 794, pers. comm., I $97 \mathrm{r}$; Crüger, 1865 , pp. 1 $32-133$, the first adversary to stress that bundles should be considered from the physiological standpoint; Eggers, 1935; Goebel, r932-33; Grégoire, 1938; Grélot, 1897; Hagemann, r963; Hall, 1954, 1956; Joshi, r948; Puri, =1951, 1952a, c, 1960, with regard to the inferior ovary; Rohweder, 1967; Siegert, 1965; Stebbins 1967; Thompson, 1936, 1937; Troll 1932; Venning, 1948. 


\section{Acknowledgements}

This study is based on a portion of a dissertation submitted in partial fulfilment of the requirements for the degree of $\mathrm{Ph}$. $\mathrm{D}$. at The University of Michigan, Ann Arbor.

I thank the following persons for their critical reading of the manuscript: Drs. Warren H. Wagner, Jr., Charles B. Beck, and Rogers McVaugh, and Messrs. Michael R. Mesler and James G. Bruce III, all of The University of Michigan; Dr. Sherwin Carlquist, Rancho Santa Ana Botanical Garden; Dr. Richard H. Eyde, Smithsonian Institution; and my wife Marvin, who also did the drawings.

\section{References}

Arber, A. 1913 - On the structure of the androecium in Parnassia and its bearing on the affinities of the genus. Ann. Bot. 27:49I-5IO.

Arber, A. 1933a - Floral anatomy and its morphological interpretation. New Phytol. 32: $23 \mathrm{I}-242$.

Arber, A. 1933b - Morphological interpretation of floral anatomy. Nature $132: 823$. (Letter.)

ARBER, A. I938 - Studies in flower structure. IV. On the gynaeceum of Papaver and related genera. Ann. Bot. 2:649-664.

BAILEY, I. W. 1949 - Origin of the angiosperms: need for a broadened outlook. J. Arnold Arb. 30:64-70.

BAILEY, I. W. I951 - The use and the abuse of anatomical data in the study of phylogeny and classification. Phytomorphology 1 :67-69.

Balley, I. W. 1953 - The anatomical approach to the study of genera. Chronica Bot. 14 : I 2 I-I 25 .

Beauverie, J., and M. Durand i 930 - L'ancienneté et la phylogénie des plantes a fleurs. Rev. Gen. Sci. Pures Appl. 41:269-278.

Bower, F. O. I 935 - Primitive land plants. New York: Hafner Publishing Co. (I959 reprint.)

BRown, R. 1833 - On the organs and mode of fecundation in Orchideae and Asclepiadeae. Trans. Linnean Soc. London $16: 68 ;-745$.

Carlquist, S. I961 - Comparative plant anatomy. New York: Holt, Rinehart and Winston.

CARLQuist, S. 1969 - Toward acceptable evolutionary interpretations of floral anatomy. Phytomorphology 19:332-362. (Issued 1970.)

Cheung, M., and R. SATtLeR 1967 - Early floral development of Lythrum salicaria. Can. J. Bot. $45: 1609-1618$.

Constance, L. I 955 - The systematics of the angiosperms. Pp. $405-483$ in A century of progress in the natural sciences, $1853-1953$. San Francisco: California Academy of Sciences.

Corner, E. J. H. 1966 - Debunking the new morphology. New Phytol. 65:398-404.

Croizat, L. 1960 - Principia botanica. Caracas: The Author.

Cronquist, A. 1968 - The evolution and classification of flowering plants. Boston: Houghton Mifflin Co.

Crüger, H. 1865 - A few notes on the fecundation of orchids and their morphology. J. Linnean Soc. Bot. 8:1 27-1 35 .

Cusick, F. 1966 - On phylogenetic and ontogenetic fusions. Pp. I70-183 in E. G. Cutter [ed.], Trends in plant morphogenesis. New York: John Wiley and Sons.

Davis, P. H., and V. H. HEYwOOD I963 - Principles of angiosperm taxonomy. Princeton, New Jersey: D. van Nostrand Co.

DE WET, J. M. J. 1968 - Diploid-tetraploid-haploid cycles and the origin of variability in Dichantbium agamospecies. Evolution 22:394-397.

Douglas, G. E. 1944 - The inferior ovary. Bot. Rev. 10:125-186.

Douglas, G. E. 1957 - Idem. II. Bot. Rev. 23:1-46.

EAmES, A. J. 1929 - The rôle of flower anatomy in the determination of angiosperm phylogeny. Proc. Int. Congr. P1. Sci., Ithaca, N. Y., Aug. 16-23, I926, x:423-427.

EAmEs, A. J. 1930-The general anatomy of the flower with special reference to the gynoe- 
cium. Fifth Int. Bot. Congr., Cambridge, Abstracts of Communications, p. I 83 .

EAmES, A. J. 193I - The vascular anatomy of the flower with refutation of the theory of carpel polymorphism. Amer. J. Bot. I $8: 147-188$.

Eames, A. J. 195 I - Again: 'The new morphology'. New Phytol. 50:17-35.

EAmes, A. J. 1953 - Floral anatomy as an aid in generic limitation. Chronica Bot. 14:126132.

EAmes, A. J. 1961 - Morphology of the angiosperms. New York: McGraw-Hill Book Co.

Eames, A. J., and L. H. MacDaniels r 925 - An introduction to plant anatomy. New York: McGraw-Hill Book Co.

Eames, A. J., and L. H. MacDaniels. I 947 -Idem. 2nd Ed. New York: McGraw-Hill Book Co.

Eggers, O. 1935 - Uber die morphologische Bedeutung des Leitbündelverlaufes in den Blüten der Rhoeadalen und über das diagramm der Cruciferen und Capparidaceen. Planta 24:14-58.

EGLER, F. E. I95 I - The terminology of floral types. Chronica Bot. 12:169-173.

EYDE, R. H. I 968 - Flowers, fruits, and phylogeny of Alangiaceae. J. Arnold Arb. 49: 167192.

EYDE, R. H. 197I - Evolutionary morphology: distinguishing ancestral structure from derived structure in flowering plants. Taxon 20:63-73.

EYDE, R. H., and C. C. Tseng 1969 - Flower of Tetraplasandra gymnocarpa: hypogyny with epigynous ancestry. Science $166: 506-508$.

EYDE, R. H., and C. C. TSENG I97 I - What is the primitive floral structure of Araliaceae? J. Arnold Arb. 52:205-239.

FaHN, A. 1967 - Plant anatomy. Trans. from Hebrew by S. Broido-Altman. Oxford: Pergamon Press,

FARRIS, J. S. 1966 - Estimation of conservatism of characters by constancy within biological populations. Evolution 20:587-591.

Goebel, K. 1932-33 - Organographie der Pflanzen insbesondere der Archegoniaten und Samenpflanzen. 3. Aufl. Tl. III. Samenpflanzen. Jena: Gustav Fischer.

GréGoIRE, V. I938 - La morphogénèse et l'autonomie morphologique de l'appareil floral. I. Le carpelle. Cellule 47:285-452.

Grélot, P. I 897 - Recherches sur le système libéroligneux floral des gamepétales bicarpellées. Ann. Sci. Nat. Bot., Sér. 8, $5: 1-154$.

Hagemann, W. 1963 - Die morphologische Sprossdifferenzierung und die Anordnung des Leitgewebes. Ber. Deut. Bot. Gesell. 76(Sondernummer):(I I 3)-(120).

Hall, B. A. I954 - Variability in the floral anatomy of Acer negundo. Amer. J. Bot. 4I : 529-532.

HeEL, W. A. vaN. I 966 - The synangial nature of pollen sacs on the strength of 'congeni-

HeEL, W. A. van. I966 - Morphology of the androecium in Malvales. Blumea $13: 177^{-}$ 394.

HeEL, W. A. van. 1969 - The synangial nature of pollen sacs on the strength of 'congenital fusion' and 'conservatism of the vascular bundle system', w. sp. ref. to some Malvales. Proc. K. Nederl. Akad. Wetenschappen, Amsterdam, Ser. C, 72:172-206.

HENsLow, G. I 888 - The origin of floral structures through insect and other agencies. London: Kegan Paul, Trench \& Co.

HensLow, G. I890 - On the vascular systems of floral organs, and their importance in the interpretation of the morphology of flowers. J. Linnean Soc. Bot. 28:1 5 I-197.

Hunt, K. W. 1937 - A study of the style and stigma, with reference to the nature of the carpel. Amer. J. Bot. 24:288-295.

JAYA WEERA, D. M. A. I956 - The morphology of the flower of Rhodomyrtus tomentosa, Wight. Ceylon J. Sci., Sect. A, Bot. 1 3:3 I-40.

JAYAWEERA, D. M. A. 1957 - Variation in the flower of Eugenia malaccensis Linn. J. Linnean Soc. London Bot. $55: 721-728$.

Joshi, A. C. 1933-Morphological interpretation of floral anatomy. Nature 1 32:822-823. (Letter.)

Joshi, A. C. $194^{\circ}$ - The conservate [sic] character of the vascular system: comparative anatomy of normal and pentaphyllous bicarpellary flowers of Gagea fascicularis. Ann. Bot. 4:664-669. 
Joshi, A. C. 1948 - The morphology of the gynoecium. Proc. 34th Indian Sci. Congr., Delhi, I947, Part II (Presidential Addresses), Sect. 6:1-1 5.

Kasapligil, B. i95 I - Morphological and ontogenetic studies of Umbellularia californica Nutt. and Laurus nobilis L. Univ. California Publ. Bot. 25 : I I -239.

Kozo-Poljanski, B. 1936 - On some 'third' conceptions in floral morphology. New Phytol. $35: 479-492$.

LAWRENCE, G. H. M. 1953 - Plant genera, their nature and definition: the need for an expanded outlook. Chronica Bot. I4:1 17-1 20.

MCLEAN, R. C., and W. R. IvimeY-Cook 1956 - Textbook of theoretical botany. Vol. II. New York: John Wiley \& Sons.

Majumdar, G. P. 1956 - Carpel morphology (appendicular v. axial controversy: a plea for re-examination). J. Asiatic Soc., Sci. 22:45-54.

Melville, R. 1963 - A new theory of the angiosperm flower: II. The androecium. Kew Bull. $17: 1-63$.

Moelıono, B. M. r 970 - Cauline or carpellary placentation among dicotyledons (Axisborne versus leaf-borne ovules). The cauline ovules of centrosperms. 2 volumes. Assen, Netherlands: Van Gorcum \& Comp. N.V.

Moseley, M. F., Jr. 196r - Morphological studies of the Nymphaeaceae. Il. The flower of Nymphaea. Bot. Gaz. 122:233-259.

Moseley, M. F., Jr. 1965 - Idem. III. The floral anatomy of Nuphar. Phytomorphology $15: 54-84$.

MosELEY, M. F., Jr. 967 - The value of the vascular system in the study of the flower. Phytomorphology 17:159-164. (Issued 1968.)

Ozenda, P. 1949 - Recherches sur les Dicotylédones apocarpiques. Contribution à l'étude des Angiospermes dites primitives. Publ. Lab. École Norm. Supér., Sér. Biol., Fasc. 2, Paris. xii, I8 3 pp.

PURI, V. 1945 - Studies in floral anatomy. III. On the origin and orientation of placental strands. Proc. Nat. Acad. Sci. India, Sect. B, is:74-9r.

PURI, V. I95 1 - The rôle of floral anatomy in the solution of morphological problems. Bot. Rev. 17:471-553.

PURI, V. I952a - Floral anatomy and inferior ovary. Phytomorphology 2:122-I29.

PURI, V. $1952 \mathrm{~b}$ - Placentation in angiosperms. Bot. Rev. $18: 603-651$.

Puri, V. $1952 \mathrm{C}$ - Floral anatomy in relation to taxonomy. Agra Univ. J. Ras. (Sci.) I 1 i 5-35.

Puri, V. r $960-$ On the methods of studying floral morphology. Proc. Nat. Inst. Sci. India, Part B, Suppl., 26:97-108.

PURI, V. I $96 x$ - The classical concept of angiosperm carpel: a reassessment. J. Indian Bot. Soc. $40: 511-524$.

PURI, V. 1962 - Floral anatomy in relation to taxonomy. Bull. Bot. Surv. India 4:161-165. (Issued 1963.)

RAO, V. S. I95 I - The vascular anatomy of flowers: a bibliography. J. Univ. Bombay i 9 $(5): 38-63$.

RAO, V. S. 1968 - Placentation in relation to anatomy. Bot. Notiser I 2 r:28 I-286.

RoHWEDER, O. 1967 - Karpellbau und Synkarpie bei Ranunculaceen. Ber. Schweiz. Bot. Gesell. 77:376-432.

SAUNDERs, E. R. 1934 - Comments on 'floral anatomy and its morphological interpretation'. New Phytol. 33:1 27-170.

SAunders, E. R. 1937 - Floral morphology. Vol. I. Cambridge: W. Heffer \& Sons Ltd.

Saunders, E. R. I 939 - Idem. Vol. II. Cambridge: W. Heffer 8 Sons Ltd.

Schmid, R. I97 I - Floral anatomy of Eugenia sensu lato (Myrtaceae). Ph. D. Thesis. The University of Michigan. vii, $217 \mathrm{pp}$.

SснміD, R. I972a - A resolution of the Eugenia-Syzygium controversy (Myrtaceae). Amer. J. Bot. $59: 423-436$.

Schmid, R. 1972b - Floral anatomy of Myrtaceae. I. Syzygium s. l. Bot. Jahrb. 92: (In press.)

Schmid, R. 1972c - Idem., II. Eugenia. J. Arnold Arb. 53: (In press.)

SIEGERT, A., 1965-Morphologische, entwicklungsgeschichtliche und systematische Studien an Psilotum triquetrum Sw. II. Die Verzweigung (mit einer allgemeinen Erörterung des Begriffes 'Dichotomie'). Beitr. Biol. Pfl. 41:209-230. 
Stebbins, G. L., Jr. 1950 - Variation and evolution in plants. New York: Columbia University Press.

Stebrins, G. L., Jr. I967 - Adaptive radiation and trends of evolution in higher plants. Pp. 101-142 in T. Dobzhansky, M. Hecht, and W. C. Steere [eds.], Evolutionary Biology, vol. I New York: Appleton-Century-Crofts, Meredith Publishing Co.

Swamy, B. G. L., and K. Periasamy 1964 - The concept of the conduplicate carpel. Phytomorphology 14:319-327.

Tepfer, S. S. 1953 - Floral anatomy and ontogeny in Aquilegia formosa var. truncata and Ranunculus repens. Univ. California Publ. Bot. 25:513-647.

Thompson, J. McLean 1936 - On the floral morphology of Elettaria cardamomum Maton. (with special reference to the interpretation of floral structure on the evidence of ontogeny and of vascular anatomy). Univ. Liverpool, Publ. Hartley Bot. Lab. $14: 3-23$.

Thompson, J. McLean I 937 - On the place of ontogeny in floral enquiry. Univ. Liverpool, Publ. Hartley Bot. Lab. 17:3-20.

TIEghem, P. VAN i 875 - Recherches sur la structure du pistil et sur l'anatomie comparée de la fleur. Mém. Acad. Sci. Inst. Impérial France, Sér. 2, 21:1-261. (Reprinted from Mém. des Savants Étrangers à l'Institut, Sér. 2, 21:1-26I, 187I).

Tillson, A. H., and R. BAmpord 1938 - The floral anatomy of the Aurantioideae. Amer. J. Bot. $25: 780-793$.

TroLl, W. I932 - Morphologie, einschliesslich Anatomie. Fortschritte der Botanik I: II 1 -25.

Unruh, M. I939 - Die morphologische Bedeutung des Karpells. Beitr. Biol. Pfl. 26:90124.

Venning, F. D. 1948 - Diversities of floral vascular anatomy in Pamburus missionis (Wight) Swingle. Q. J. Florida Acad. Sci. 10:1 39-1 46.

Wardlaw, C. W. 1965 - Organization and evolution in plants. London: Longmans, Green and Co.

WILson, C. L. 1950 - Vasculation of the stamen in the Melastomaceae, with some phyletic implications. Amer. J. Bot. 37:43 1-444.

WILson, C. L., and T. TUst 1939 - The morphology of the flower. Bot. Rev. 5:97-1 31 . 